\title{
Agroforestry: A Supplementary Method for Biodiversity Conservation and Climate Change Mitigation and Adaptation
}

\author{
Kassahun Mulatu ${ }^{1}$, *, Debela Hunde ${ }^{2}$ \\ ${ }^{1}$ Department of Natural Resource Management, College of Agriculture And Natural Resource, Mizan Tepi University, Mizan Teferi, Ethiopia \\ ${ }^{2}$ Department of Natural Resource Management, College of Agriculture and Veterinary Medicine, Jimma University, Jimma, Ethiopia
}

Email address:

kassahunm1972@gmail.com (K. Mulatu)

${ }^{*}$ Corresponding author

To cite this article:

Kassahun Mulatu, Debela Hunde. Agroforestry: A Supplementary Method for Biodiversity Conservation and Climate Change Mitigation and Adaptation. International Journal of Ecotoxicology and Ecobiology. Vol. 5, No. 3, 2020, pp. 29-35. doi: 10.11648/j.ijee.20200503.11

Received: September 20, 2019; Accepted: May 25, 2020; Published: September 16, 2020

\begin{abstract}
Biodiversity conservation in current era of increasing global climate change and rapid land degradation is a major challenge globally. Agroforestry is an important land use system addressing biodiversity conservation and enhancing social and environmental goals. However, there is scarcity of empirical evidence on contributions of agroforestry for conservation of biodiversity and reduction of $\mathrm{CO}_{2}$ emission. This paper aimed to provide empirical information on the role of agroforestry for conservation of flora and fauna biodiversity and climate change mitigation and adaptation. The result revealed agroforestry has contributed huge role in conservation of fauna and flora diversity and mitigation of $\mathrm{CO}_{2}$ than open cereal based agriculture. Trees in agroforestry are the important component in conservation and mitigation of climate change effects. Binding $\mathrm{CO}_{2}$ through biomass and soil, reducing other causes for $\mathrm{CO}_{2}$ emission such as deforestation and microclimate modification are major climate change mitigation actions. Provision of numerous other ecosystem services to people and their agroecosystem such as provisioning services (shelter, food, fodder, etc.), regulating services (pest and diseases control, modification of microclimate, reducing wind effect, etc.) and supporting services (nutrient cycling) help them build the resilience towards changing climate effects. Hence, responsible bodies must consider the huge potential of agroforestry in their conservation and climate change mitigation and adaption strategy.
\end{abstract}

Keywords: Agroforestry, Supplementary Method, Flora and Fauna Diversity, Mitigation of $\mathrm{CO}_{2}$, Ecosystem Services

\section{Introduction}

Biodiversity is crucial for human well-beings. They form the foundation for vast array of ecosystem services including climate change mitigation and adaptation. However, they are severely degraded due to land use land cover (LULC) change and climate change worldwide. Agricultural intensification, including its $60 \%$ share for forest conversion in Africa [1] has resulted in a loss of biodiversity, ecological function, and critical ecosystem services in human modified landscapes [2]. The current estimate revealed earth's has lost over 3/4 its biodiversity [3] rapidly especially in last 50 years. Thus, the loss of biodiversity such as agrobiodiversity and climate change has threating the sustainability of agriculture [4] thereby greatly threats the livelihoods of peoples in developing countries.
Agroforestry as integrated land uses system has suggested as a potential to simultaneously safeguard agriculture productivity, reduce biodiversity loss and mitigation and adaptation of climate change effects [5]. The tree components in agroforestry can significantly improve ecosystem functions that underpin ecosystem services [6]. The interactions among the components often have complementarity effects in the agroforestry system. The semi-natural vegetation provides shelters for many species [7]. Besides, the carbon sequestration in vegetation biomass and soil system plays important roles in climate change mitigation. The numerous direct and indirect ecosystem services they provide to people and agroecosystem enhancing their resilience or adaptation towards climate extremes [8].

However, the conservation role agroforestry is 
undeveloped and remains largely unexplored [9]. Due to the lack of quantitative information, the understanding of agroforestry potential for $\mathrm{CO}_{2}$ sequestration is limited. Most discussions on carbon sequestration potential of agroforestry systems are based more on hypothetical considerations than empirical results [10]. Furthermore, the links between agroforestry and livelihood resilience of households to climate change variability lacks empirical evidence [11]. The above all suggested there is shortage and fragmentation of empirical evidences. Therefore, the objective of this paper is to provide empirical evidence on the role of agroforestry in conservation of floral and faunal diversity and climate change mitigation and adaptation in contemporary situation when rapid biodiversity loss and climate change are perplexing and suggested future prospect.

\section{Potential of Agroforestry for Biodiversity Conservation and Climate Change Mitigation and Adaptation}

\subsection{Agroforestry for Biodiversity Conservation}

\section{Agroforestry for conservation of floral diversity}

Agroforestry practices increase the levels of wild biodiversity on farm land as in situ conservation method. The role agroforestry play in conservation varies across the type and management of agroforestry (Table 1) [12].

Table 1. Biodiversity dimensions in traditional agroforestry systems in the tropics.

\begin{tabular}{ll}
\hline Agroforestry system & Biodiversity issues \\
\hline $\begin{array}{l}\text { Shifting cultivation } \\
\text { or slash-and-burn }\end{array}$ & $\begin{array}{l}\text { Fallows consist of multiple species; and } \\
\text { biological diversity, in both inter- and intra- } \\
\text { species, is intense. Long fallow periods of 15 to } \\
\text { 20 years preserve wild species diversity } \\
\text { High inter- and intra-species diversity involving a } \\
\text { number of fruit, fodder and timber trees and }\end{array}$ \\
$\begin{array}{l}\text { Homegardens and } \\
\text { sompound farms } \\
\text { economic value }\end{array}$ \\
$\begin{array}{l}\text { Maintain high species diversity similar to natural } \\
\text { forests but dominated by a few carefully managed } \\
\text { agroforests }\end{array}$ & $\begin{array}{l}\text { A variety of crops grown in association with } \\
\text { naturally propagated trees ensure wide species } \\
\text { diversity. Parks range from monospecific to }\end{array}$ \\
Parkland systems & multispecific with up to 20 tree species. \\
& $\begin{array}{l}\text { Diversity is more at the landscape level rather } \\
\text { than at field level in terms of both inter- and intra- } \\
\text { species. }\end{array}$ \\
\hline
\end{tabular}

Source: [12].

Thus, different number and composition of plant species including exotic and native species were recorded in different agroforestry (Table 2). Studies, revealed agroforestry has a huge potential for conservation of socioeconomically and environmentally important species of indigenous trees used for various services such as fodder, food, medicine, fuel wood, farm tools and wood for utensils [13]. Farmers deliberately maintained annual and perennial herbs and woody species of diverse plant categories for fulfilling the subsistence and cash needs [14]. According to this study, 159 species were recorded in homegarden, of which $70.44 \%$ were categorized as useful to community. Agroforestry is also important refuge for native and endangered species in agricultural landscapes. For instance, from 50 woody species identified by [15] in traditional agroforestry in Southeastern Ethiopia, 85\% were obtained native. In Ethiopia, agroforestry conserve endangered and national priority plant species such as Cordia africana as reported in different agroforestry system (Figure 1). The coffee based agroforestry in the southwestern part of Ethiopia maintaining a quite very good number of native plants, for instance, [16] reported more than $59 \%$ native woody species including 22 species of interest for conservation to IUCN Red lists out of 155 species. Among these, rare/threatened species, such as Baphia nitida, Cordia africana, Manilkara hexandra, Prunus africana, Pygeum africanum and Rhus glutinosa were categorized as vulnerable in the wild, and need of conservation priority.

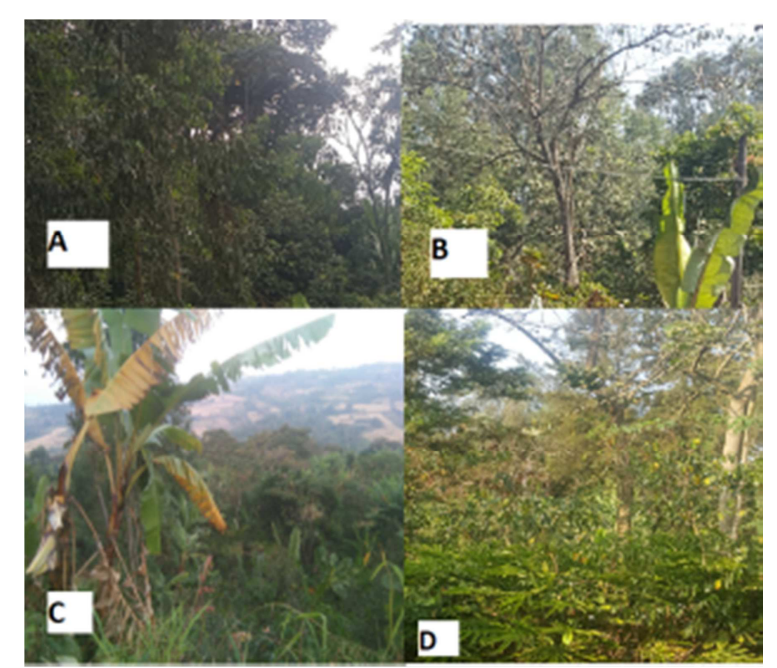

Figure 1. Diversity of species in homegarden agroforestry consists of Cordia african (A, B, C\&D), Aframomum corrorima (D, Enset ventricosum (A\&B), Musa paradisiaca $(C)$ (Photos taken from Bench-Maji zone $(A \& C)$ and Jimma zone (B\&D) by Author).

Numerous studies also revealed different potentials among different agroforestry practices for conservation of native species. For instance, among three agroforestry practices such as enset (Enset ventricosum)-based agroforestry, ensetcoffee-based agroforestry and fruit-coffee-based agroforestry, enset based agroforestry maintain $92 \%$ of native species followed by enset-coffee-agroforestry ( $89 \%$ ) from a total 58 woody species recorded [17]. Besides, from a total of 231 tree species identified by [18] from eight different agroforestry, $78 \%$ of them found to be native in Atlantic Rainforest biome. In some part of southwest Ethiopia, agroforestry consist $30 \%$ and $36 \%$ higher species of more commonly used species than evergreen natural forest and cropland respectively [19]. Other study also revealed coffee based agroforestry systems can conserve over $60 \%$ of woody species and associated biodiversity when compared to natural forest [20]. This study also reported higher number woody 
species in agroforestry than natural forest reserves. The practice of purposeful retaining of economically and biologically valuable native species such as Cordia africana, Ficus sycomorus Ficus vasta, Juniperus procera, Croton macrostachyus and Sapium ellipcum in 'farmland agroforestry' have also contributed for conservation of economically and ecologically valuable bird species such as Anomalospiza imberbis and Hirundo aethopica on smallholder farmland in Ethiopia [21]. According to different studies (Table 2), well-established traditional agroforestry can conserve $62 \%-100 \%$ of native plant species.

Table 2. Role of agroforestry practice for conservation of native species.

\begin{tabular}{|c|c|c|c|}
\hline \multirow{2}{*}{ Agroforestry practice } & \multicolumn{2}{|c|}{ Number of species } & \multirow{2}{*}{ Sources } \\
\hline & Total No of spp. count & \% native spp. & \\
\hline Coffee agroforestry & 63 & 73 & {$[22]$} \\
\hline Enset-AF, Enset-coffee-AF and Fruit-coffee-AF & 58 & 86 & [17] \\
\hline Homegarden & 36 & 62.5 & [23] \\
\hline Traditional AF & 55 & 85 & {$[15]$} \\
\hline Farmland (Homesteads, line plantings, in crop lands and woodlots) & 77 & 70 & [24] \\
\hline Homegardens & 419 & 60 & {$[25]$} \\
\hline Different AF practice & 231 & 78 & [18] \\
\hline Homegarden, Parkland, woodlot & 80 & 71 & [27] \\
\hline Traditional agroforestry & 86 & 83 & {$[28]$} \\
\hline Homegarden & 120 & 100 & [29] \\
\hline
\end{tabular}

Despite its poor substitute for the natural forest, agroforestry can act as buffer between protected and intensively managed areas thereby strategically benefits both sustainable agriculture production and conservation of plant diversity [30]. In dryland areas with scarce moisture and degraded land, agroforestry can be an alternative for biodiversity conservation in addition to area closures activities [31]. The above evidence, therefore, indicated the huge potential of agroforestry in conservation of native flora diversity when compared to open cereal based agriculture and monocropping. Thus, endeavor in conservation of biodiversity must appreciate this potential and used it as supplementary methods for conservation of native, endemic, and rare/endangered species of plants.

Agroforestry for conservation of faunal diversity

Agroforestry can create diverse habitat for wild species including conservation of wild animal. Tree species retained in agricultural landscapes contribute range of ecosystem services to animal diversity including habitat, food and maintenance of landscape connectivity (corridors) for their free movements. Trees can contribute nesting sites, protective cover against predators, access to breeding territory, access to food sources in all seasons, and encourage beneficial species such as pollinators [32].

The vast covers of cocoa agroforestry in tropical area are considered to be the biodiversity reservoirs for some of the rainforest insect species [33]. The more complex and suitable environment provided by multistrata agroforestry helps various insect species than monocropping fields. Study in Costa Rica revealed bat and birds assemblages as (or more) species rich, abundant and diverse as forests despite the species composition of birds assemblages was highly modified, with fewer forest dependent species, more open area species and different dominant species in agroforestry systems [34]. Similarly, 106 bird species mostly preferring open areas occurred in agroforestry in Costa Rica [35]. Other study also reported over 20,000 individuals of 189 species including 14 endangered bird species in tropical agroforestry [36]. However, species assemblages were differed among different tree cover types in agricultural landscape. The shade-grown coffee and cocoa systems in Southeast Asia and Central America are known by their provision of habitat for diverse populations of birds [37]. Agroforestry also contain significantly greater (when compared to plantation monocultures) insect diversity with a total of 132,460 dung beetles of 52 species and 913 tracks of 27 terrestrial mammal species in indigenous agroforestry systems [37]. Other study also found similar species richness but differed in composition of ants and beetles in the canopies of the cacao trees compared lower canopy forest trees [38]. Agroforestry also maintained comparable diversity and abundance of soil invertebrates with miombo woodlands [39].

However, the conservation of higher wild animal (mammals) species was challenged by heavy hunting pressure [40] and conflicts between human being and wildlife. Encroachment of wildlife population into the adjacent farmland and around living house due to loss of natural habitat and feeding site for wildlife species has caused conflicts with human being and are also the major causes for the removal of tree and fruits around homes (homegarden) and at cropland. This in turn reduces the habitats and resource availability for different wild animal species. In some area (e.g. Ethiopia), farmers reduce forest and tree cover in farmland to mitigate crop damage by wild mammals such as baboons and bush pigs [41]. Similar practices of removing different tree cover (both tree and fruit tree) around home were common in Jimma city to reduce disturbance of wildlife [23].

Despite of the above challenges, agroforestry systems is still an important refuge for faunal diversity when compared to of monocultures and other open agriculture. But, there is also scarcity of studies to elucidate this potential widely. Therefore, improving tree/woody cover in agricultural land, control hunting and awareness creation 
can increase the contribution of agroforestry for faunal diversity conservation.

\subsection{Agroforestry for Climate Change Mitigation}

Agroforestry is biological greenhouse gas (GHG) such as $\mathrm{CO}_{2}$ mitigation strategy under the Kyoto Protocol [42]. The tree component in smallholder agroforestry systems are the important sinks of atmospheric carbon. The indirect role they play in reduction of deforestation and soil erosion contribute for reduction of GHG emission.

Various studies reported different amount of carbon in different agroforestry system across the world. For instance, about $2.1 \times 10^{9} \mathrm{MgC}$ year $^{-1}$ and $1.9 \times 10^{9} \mathrm{Mg} \mathrm{C}$ year $^{-1}$ were estimated from above ground components of agroforestry in tropical and temperate biomes respectively [43]. A range carbon from 0.3 to $15 \mathrm{Mg} \mathrm{C}^{-1} \mathrm{year}^{-1}$ in above ground and 30-300 Mg C ha ${ }^{-1}$ up to $1 \mathrm{~m}$ depth of soil were also recorded [44]. Studies in tropical agroforestry system revealed soil (1m depth of soil) under agroforestry system stored huge but different potential of carbon storage across different agroecological zone (Table 3) [42].

Table 3. Soil carbon stock of tropical agroforestry systems.

\begin{tabular}{lll}
\hline Agroecological zones & Major Agroforestry systems & $\begin{array}{l}\text { Soil organic } \\
\mathbf{C}\left(\mathbf{M g} \mathbf{~ h a}^{-\mathbf{1}}\right)\end{array}$ \\
\hline & Shaded perennial systems & $21-35$ \\
& Alley cropping & $10-25$ \\
Humid lowlands & Hoproved fallows & $135-149$ \\
& Tree intercropping & $108-119$ \\
& Silvopasture & $27-78$ \\
Tropical highlands & Woodlots & $96-173$ \\
& Shaded perennial systems & $61-75$ \\
Arid and semiarid & Silvopastoral systems & $132-97$ \\
lowlands & Fodder banks & 33 \\
& Live fences & $5.20-24$ \\
& Grazing systems & $12.64-33$ \\
& Crop dominated & $20-70$ \\
& Fodder dominated & $25-80$ \\
& Fuelwood dominated & $30-90$ \\
\hline
\end{tabular}

Source: Modified from [42].

Agroforestry in urban area are also crucial for climate change mitigation. For instance, a total of 2,877.13 $\mathrm{Mg} \mathrm{ha}^{-1}$ was reported from homegarden and tree planted in government institutions of Jimma City, Ethiopia [23]. On average, different agroforestry stored 448,76 and $51 \mathrm{Mg} \mathrm{ha}^{-1}$ of carbon in woodlot, homegarden and parklands respectively [26]. The efficiency of sequestering carbon in different system, for instance, in above ground and soil is also different across different agroforestry practices. Accordingly, improved fallows are more effective for above ground carbon storage while silvopastoral systems are more effective in soil carbon sequestration [45]. The low decomposition in shadedperennial-crop-based agroforestry systems has great potential for soil carbon sequestration than open cereal based agriculture. Other study also showed improved systems has greater potential to sequester carbon from the atmosphere
[46]. When compared to other land uses system without trees, agroforestry provides much higher amount of carbon through storage in the above ground and below ground biomass of agroforestry system. Study in India showed agroforestry has potential of sequestering $26 \%$ more carbon than croplands [47]. Soil under agroforestry system also stored comparable amount of carbon, for instance, $406 \mathrm{Mg} \mathrm{C} \mathrm{ha}^{-1}$ from agroforestry vis-a-vis $412 \mathrm{Mg} \mathrm{ha}^{-1}$ from natural forest in southwest Ethiopia [48]. Other study also reported that semiforest coffee agroforestry retains $75 \%$ of the carbon stored in natural forests in Ethiopia [49].

The above evidence showed agroforestry is very hopeful in mitigating climate change due to its continuous increasing in occupying majority (about $80 \%$ ) of land surface and with diverse potential of sequestrating carbon in soil, above ground and even in atmosphere when compared to other open non-tree agricultural land. Therefore, long term contribution of agroforestry for mitigation of $\mathrm{CO}_{2}$ can be achieved through increasing woody species and shade cover with appropriate consideration tradeoffs.

\subsection{Agroforestry for Climate Change Adaptation}

Climate change poses substantial threats to subsistence agriculture production in tropical Africa. Besides, agricultural production in Africa has undergone sustainability challenges due to degradation of soil fertility, water stress and biodiversity loss. Because of these the productivity of major cereals crops such as maize has been stagnated at 1 tone $\mathrm{ha}^{-1}$ [50]. This significantly threats the livelihoods of households in climate change and variability vulnerable area. However, agroforestry mitigate this effect through improving soil fertility, improving environmental quality through pollution reduction from erosion and dust as well as provision of lots of possible combinations of food products including crops and fruits, fodder, mulch/green manure and timber [51].

The trees components create a more diverse, productive and ecologically sound land use and environment [51]. The amount of shade cover play direct role in mitigation of variability in microclimate and soil moisture conservation. This protect the crop of interest from extremes climate events hence reduce the risk of crop failure or reduction of crop productivity. Report indicated, such services can increase crop yield to $50 \%$, maintained $93 \%$ of crop pollinators and reduces the incidences of pests such as coffee berry borer to $86 \%$ [6]. Fertilizer trees species (FTS) are widely documented to substantially increase maize yields compared to maize production without fertilizer in Zambia [52]. Reports from Malawi also revealed the increases of yields of maize by $110-190 \%$ due to agroforestry [51]. The fodder trees in agroforestry system are particularly important in the highlands of Eastern Africa for dairy farmers [53]. The role of trees and shrubs in reducing soil erosion, improving soil productivity, buffering microclimates, provision of green fodder, fruits and leaves for human consumption and income generation [51] improve the livelihoods subsistence farmers. Agroforestry can also protect farm production through their naturally occurring co-benefits including enhanced nutrient 
cycling, integrated pest management and increased resistance to diseases [6]. In sub-Saharan Africa (SSA), agroforestry provide more accessible, safe and stable source of fuelwood for energy [54]. Besides, it helps small scale honey production through traditional methods [53] vital for income generation in many parts of developing countries (Figure 2).

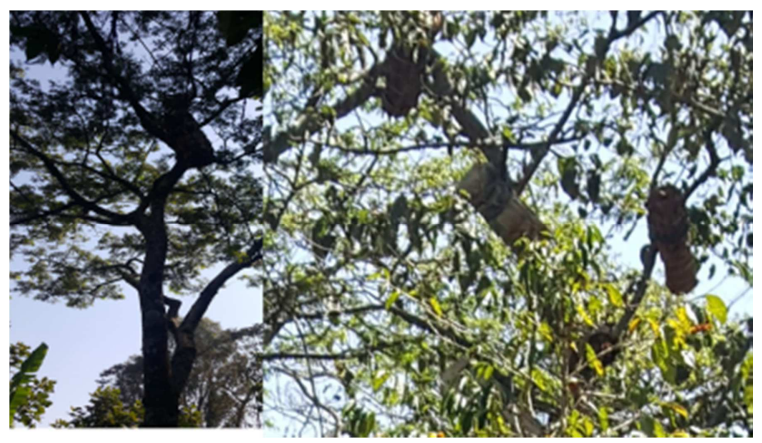

Figure 1. Traditional bee hives hanged on Acacia spp. (left) and Albizia schimperiana (right) in agroforestry system in Jimma zone (Photo by Author).

Agroforestry also help households through reducing risk of production failure by diversifying enterprises and income sources, protecting crops and resources from high wind storms thereby increasing resilience associated with climate change [51]. Therefore, agroforestry is essential land use system having great potential to provide numerous ecosystem services directly and indirectly support people and their agroecosystem to build resilience to climate variability and change effects.

\section{Conclusion and Recommendation}

Agroforestry systems have played an important function in conservation of both flora and fauna, reducing $\mathrm{CO}_{2}$ emission and enhancing the resilience of people and their agroecosystem to climate variability and change. The tree components in agroforestry serve a key role in provision of diverse ecosystem function and services. The purposive retaining of multipurpose trees including native species in agroforestry provides huge opportunity for the conservation of rare/endangered or endemic species plant and wildlife. The role they playing in binding carbon (both in biomass and soil), improving environmental quality (reducing erosion, improving soil quality, retaining soil moisture and modifying microclimate), protecting crops failure due to wind, pest and diseases, and provision of lots of possible combinations direct ecosystem services including food products and income generation provide essential support in fighting against climate change effects. Hence, the number of direct and indirect ecosystem services agroforestry provide at different scale including at household and community as well as at farm and landscapes level support people and their agroecosystem to build resilience against climate change and help vulnerable people to run sustainable livelihoods (Figure $3)$.

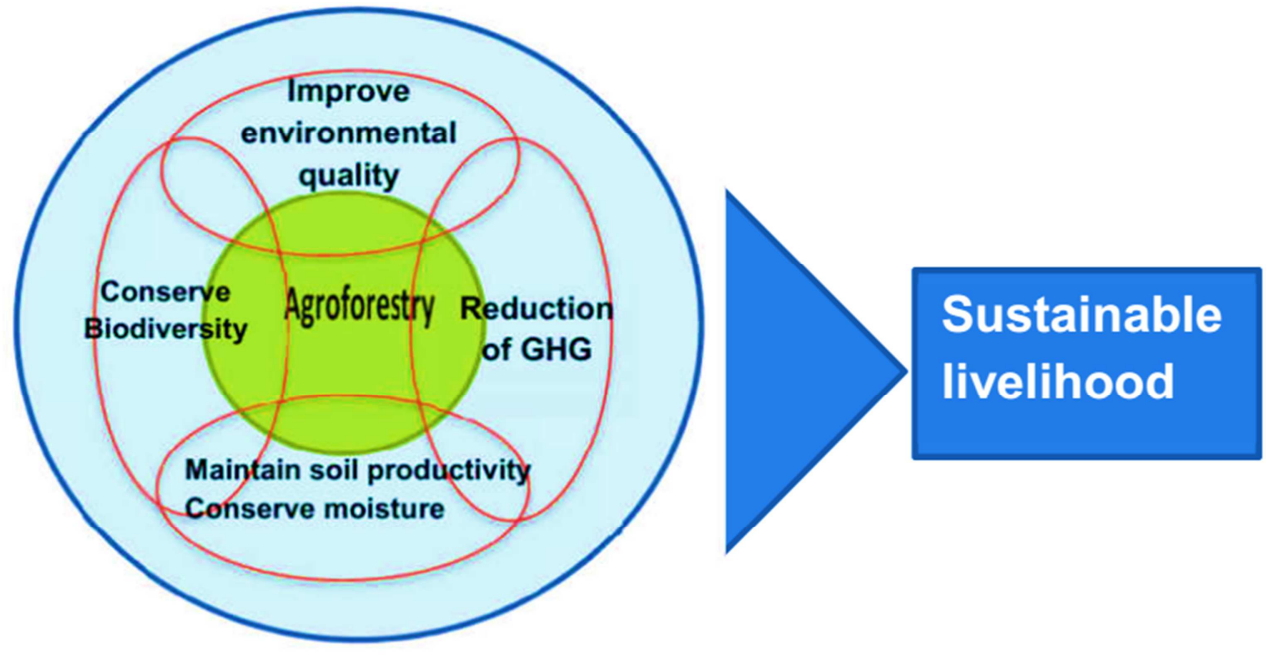

Figure 2. Role of agroforestry in environmental conservation.

Therefore, proper understanding of the potential of agroforestry and its implementation as supplementary tools requires awareness at all level and support to landowners in terms of technical knowhow and access to and choice of appropriate planting species and management.

Hence, future research should be emphasized on:

1. Identification of plant species to be included in agroforestry and integration agroforestry components and their management approaches that can maximize socioeconomic benefits and environmental sustainability;

2. Analysis of different ecosystem services delivered by different agroforestry system;

3. Studies on the role of agroforestry for conservation of fauna (both below and above ground) should be improved.

4. Further study on the roles of urban agroforestry and vegetation for conservation biodiversity and climate change regulation and food security is important to fill knowledge gaps in urban area. 


\section{References}

[1] Hosonuma, N., Herold, M., De Sy, V., De Fries, R. S., Brockhaus, M., Verchot, L., Angelsen, A. and Romijn, E. (2012). An assessment of deforestation and forest degradation drivers in developing countries. Environmental Research Letters, 7 (4): 0044009, 12.

[2] Landis, D. A. (2016). Designing agricultural landscapes for biodiversity-based ecosystem services. Basic and Applied Ecology. http://dx.doi.org/10.1016/j.baae.2016.07.005.

[3] Barnosky, A. D., Matzke, N., Tomiya, S., Wogan, G. O., Swartz, B., Quental, T. B., Marshall, C., McGuire, J. L., Lindsey, E. L., Maguire, K. C. and Mersey, B. (2011). Has the Earth's sixth mass extinction already arrived?. Nature, 471 (7336).51.

[4] Cotter, J. and Tirado, R. (2008). Food Security and Climate Change: The answer is biodiversity. A review of scientific publications on climate change adaptation in agriculture.

[5] Getachew, M. and Mesfin, A. (2014). Woody Species Diversity and Their Preferences on Farmers, Landholding. Journal of Natural Science Research, 4 (9): 96-108.

[6] Barrios, E., Valencia, V., Onsson, M. J., Brauman, A., Hairiah, K., Mortimer, P. E., Okubo, S. (2018). Contribution of Trees to the Conservation of Biodiversity and Ecosystem Services in Agricultural Landscapes. International Journal of Biodiversity Science, Ecosystem Services \& Management, 14 (1): 1-16.

[7] Hartoyo, A. P. P., Siregar, I. Z., Supriyanto, Prasetyo, L. B., and Theilade, I. (2016). Biodiversity, carbon stocks and community monitoring in traditional agroforestry practices: preliminary results from two investigated villages in Berau, East Kalimantan. Procedia Environmental Sciences, 33: 376385 .

[8] Waldron A, Garrity D, Malhi Y, Girardin C, Miller DC, Seddon N (2017). Agroforestry Can Enhance Food Security While Meeting Other Sustainable Development Goals Tropical Conservation Science. 10: 1-6.

[9] Seta, Tand Demissew, S. (2017). Diversity and standing carbon stocks of Agroforestry trees in Wenago District, Ethiopia. International Journal of Agroforestry and Silviculture, 4 (1): 246-256.

[10] Kumar, V. (2017). Importance of Homegardens Agroforestry System in Tropics Region. Biodiversity, Conservation and Sustainable Development. New Academic Publishers, New Delhi, India.

[11] Nair, P. K. R, and Garrity, D. (2012). Agroforestry research and development: the way forward. In: Nair, P. K. R., and Garrity, D. (Eds.). Agroforestry - the future of global land use: advances in agroforestry. Volume 9.

[12] Atta-Krah, K., Kindt, R., Skilton, J. N., and Amaral, W. (2004). Managing biological and genetic diversity in tropical agroforestry. Agroforestry Systems, 61: 183-194.

[13] Worku, M. and Bantihun, A. (2017). Review on Woody Species and SocioEconomic Roles of Traditional Agroforestry Practices in Ethiopia. Journal of Fundam Renewable Energy, 7: 246.
[14] Talemos, S., Sebsebe, D. and Zemede, A. (2013). Home gardens of Wolayta, southern Ethiopia: An ethnobotonical profile. Acad. J. Med. Plants, 1 (1): 14-30.

[15] Molla, A. and Kewessa, G. (2015). Woody Species Diversity in Traditional Agroforestry Practices of Dellomenna District, Southeastern Ethiopia: Implication for Maintaining Native Woody Species. Hindawi Publishing Corporation: International Journal of Biodiversity, 1-13.

[16] Tadesse, G., Zavaleta, E. and Shennan, C. (2014). Coffee landscapes as refugia for native woody biodiversity as forest loss continues in southwest Ethiopia. Biological Conservation. $169,384-391$.

[17] Negash, M., Eshetu Y, Olavi L (2012). "Potential of indigenous multistrata agroforests for maintaining native floristic diversity in the south-eastern Rift Valley escarpment, Ethiopia." Agroforestry systems, 85 (1): 1: 9-28.

[18] De Souza, H. N., Ron de Goede, G. M., Brussaard, L., Cardoso, I. M., Duarte Edivania, M. G., Fernandes Raphael, B. A., Gomes, L. C. and Pulleman, M. M. (2012). Protective shade, tree diversity and soil properties in coffee agroforestry systems in the Atlantic Rainforest biome. Agriculture, Ecosystems and Environment, 146: 179-196.

[19] Kassa, H., Dondeyne, S., Poesen, J., Frankl, A. and Nyssen, J. (2018). Agro-ecological implications of forest and agroforestry systems conversion to cereal-based farming systems in the White Nile Basin, Ethiopia. Agroecology and Sustainable Food Systems, 42 (2): 149-168.

[20] Tadesse, E. G. (2013). Biodiversity and Livelihoods in Southwestern Ethiopia: Forest Loss and Prospects for Conservation in Shade Coffee Agroecosystems. A dissertation submitted to University of California.

[21] Amare, D., Wondie, M., Mekuria, W. and Darr, D. (2018). Agroforestry of Smallholder Farmers in Ethiopia: Practices and Benefits. Small-scale Forestry. Available at: https://www.researchgate.net/publication/327318027.

[22] Negawo, W and Beyene, D. (2017). The Role of Coffee Based Agroforestry System in Tree Diversity Conservation in Eastern Uganda. Journal of Landscape Ecology, 10 (2): 1-18.

[23] Mulatu, K. (2019). Urban Homegarden for Woody Species Conservation and Carbon Sequestration: The Case of Jimma City, Southwest Ethiopia. Journal of Natural Sciences Research, 9 (13): 30-31.

[24] Endale, Y., Derero, A., Argaw, M., and Muthuri, C. (2016). Farmland tree species diversity and spatial distribution pattern in semi-arid East Shewa, Ethiopia. Forests, trees and LiveLihoods.

[25] Kabir, M. E. and Webb, E. L. (2009). Household and homegarden characteristics in southwestern Bangladesh. Agrofor Syst, 75: 129-145.

[26] Bajigo, A., Tadesse, M., Moges, Y. and Anjulo, A. (2015). Estimation of Carbon Stored in Agroforestry Practices in Gununo Watershed, Wolayitta Zone, Ethiopia. J Ecosys Ecograph, 5: 157.

[27] Ashebir, K. (2011). Woody Species Diversity and Management in Traditional Agroforestry Practices in Yeki Woreda, Sheka Zone, Southwestern Ethiopia. M. Sc. Thesis, College of Agriculture, Hawassa University. 
[28] Asfaw, B. and Lemenih, M. (2010). Traditional Agroforestry Systems as a Safe Haven for Woody Plant Species: A Case Study from a Topo-Climatic Gradient in South Central Ethiopia. Forests, Trees and Livelihoods, 19: 359-377.

[29] Abebe, T. (2005). Diversity in homegarden agroforestry systems of Southern Ethiopia. Tropical Resource Management Paper, No 59.

[30] Asase, A. and Tetteh, D. A. (2010). The role of complex agroforestry systems in the conservation of forest tree diversity and structure in southeastern Ghana. Agroforest Syst., 79: $355-368$.

[31] Guyassa, E. and Joseph Raj, A. (2013). Assessment of biodiversity in cropland agroforestry and its role in livelihood development in dryland areas: A case study from Tigray region, Ethiopia. Journal of Agricultural Technology, 9 (4): 829-844.

[32] Ndolo, M. C, Dharani, N. and Kehlenbeck, K. (2016). Socioeconomic and Biophysical Factors Affecting Tree Richness and Diversity in Machakos County, Eastern Kenya. International Journal of Plant, Animal and Environmental Sciences, 6 (3). Xx.

[33] Perry, J., Lojka, B., Quinones Ruiz, L. G., Van Damme, P., Houška, J. and Cusimamani, E. F. (2016). How natural Forest Conversion Affects Insect Biodiversity in the Peruvian Amazon: Can Agroforestry Help? Forests, 7: 82.

[34] Harvey, C. A. and Villalobos, J. A. G. (2007). Agroforestry systems conserve species-rich but modified assemblages of tropical birds and bats. Biodiversity and Conservation, 16 (8): 2257-2292.

[35] Greenler, S. M, and Ebersole, J. J. (2015). Bird communities in tropical agroforestry ecosystems: an underappreciated conservation resource. Agroforestry systems, 89 (4): 691-704.

[36] McNeely, J. A., Schroth, G. (2006). Agroforestry and biodiversity conservation- traditional practices, present dynamics, and lessons for the future. Biodiversity \& Conservation, 15 (2): 549-554.

[37] Buck, L. E., Gavin, T. A., Lee, D. R., Uphoff, N. T., Behr, D. C., Drinkwater, L. E., Hively, W. D. and Werner, F. R. (2004) Ecoagriculture: A Review and Assessment of its Scientific Foundations. Cornell University, Ithaca, USA.

[38] Boffa, J. M., Turyomurugyendo, L., Barnekow-Lillesø, J. and Kindt, R. (2005). Enhancing Farm Tree Diversity as a Means of Conserving Landscape-based Biodiversity. Mountain Research and Development, 25 (3): 212-217.

[39] Sileshi, G., Mafongoya, P. L., Kwesiga, F. and Nkunika, P. (2005). Termite damage to maize grown in agroforestry systems, traditional fallows and monoculture on Nitrogenlimited soils in eastern Zambia. Agr. For. Entomol, 7: 61-69.

[40] Henry, M., Tittonell, P., Manlay, R. J., Bernoux, M., Albrecht, A. and Vanlauw, E. B. (2009). Biodiversity, carbon stocks and sequestration potential in aboveground biomass in smallholder farming systems of western Kenya. Agriculture, Ecosystems and Environment, 129: 238-252.

[41] Ango, G. T., Börjeson, O. L. and Senbeta, F. (2017). Crop raiding by wild mammals in Ethiopia: Impacts on the livelihoods of smallholders in an agriculture-forest mosaic landscape. Oryx, 51: 527-537.

[42] Nair, P. K. R., Nair, V. D., Kumar, B. M. and Haile, S. G. (2009). Soil carbon sequestration in tropical Agroforestry systems: a feasibility appraisal. Environmental Science and Policy, 12: 1099-1111.

[43] Oelbermann, M., Voroney, R. P. and Gordon, A. M. (2004). Carbon sequestration in tropical and temperate agroforestry systems: a review with examples from Costa Rica and southern Canada Agriculture. Ecosystems and Environment, 104: 359-377.

[44] Nair, P. K. R., Nair, V. D., Kumar, B. M. and Showalter, J. M. (2010). Carbon sequestration in agroforestry systems. Adv. Agron, 108: 237-307.

[45] Feliciano, D., Ledo, A., Hillier, J. and Nayak, D. R. (2018). Which agroforestry options give the greatest soil and above ground carbon benefits in different world regions? Agriculture, Ecosystems and Environment, 254: 117-129.

[46] Takimoto, A., Nair, P. K. R. and Nair, V. D. (2008). Carbon stock and sequestration potential of traditional and improved agroforestry systems in the West African Sahel. Agriculture, Ecosystems and Environment, 125: 159-166.

[47] Murthy, I. K., Gupta, M., Tomar, S., Munsi, M., Tiwari, R., and Hegde, G. and Ravindranath N. H. (2013). Carbon Sequestration Potential of Agroforestry Systems in India. J Earth Sci Climate Change, 4: 131.

[48] Kassa, H., Dondeyne, S., Poesen, J., Frankl, A. and Nyssen, J. (2017). Impact of deforestation on soil fertility, soil carbon and nitrogen stocks: the case of the Gacheb catchment in the White Nile Basin, Ethiopia. Agriculture, Ecosystems and Environment, 247: 273-282.

[49] Denu, D., Platts, P. J., Kelbessa, E., Golee, T. W. and Marchant, R. (2016). The role of traditional coffee management in forest conservation and carbon storage in the Jimma Highlands, Ethiopia. Forests, trees and LiveLihoods.

[50] Carsan, S., Stroebel, A., Dawson, I., Kindt, R., Mbow, C., Mowo, J. and Jamnadass, R. (2014). Can agroforestry option values improve the functioning of drivers of agricultural intensification in Africa? Current pinion in Environmental Sustainability, 6: 35-40.

[51] Schaller, M., Barth, E., Blies, D., Röhrig, F. and Schümmelfeder, M. (2017). Climate Smart Agriculture (CSA): Climate Smart Agroforestry.

[52] Pretty, J., Toulmin, C. and Williams, S. (2011). Sustainable intensification in African agriculture. International journal of agricultural sustainability, 9 (1): 5-24.

[53] Franzel, S., Carsan, S., Lukuyu, B., Sinja, J. and Wambugu, C. (2014). Fodder trees for improving livestock productivity and smallholder livelihoods in Africa. Current Opinion in Environmental Sustainability, 6: 98-103.

[54] Thorlakson, T. and Neufeldt, H. (2012). Reducing subsistence farmers' vulnerability to climate change: evaluating the potential contributions of agroforestry in Western Kenya. Agric. Food Security, 1: 15. 